\title{
Using an operating microscope to re-treat an inferior premolar with two canals
}

\author{
Uso do microscópio operatório no retratamento de um pré-molar inferior com dois canais
}

Janaína Fernandes SANTOS 1

Gustavo Moreira ALMEIDA'

Eduardo Fernandes MARQUES 1

Carlos Eduardo da Silveira BUENO2

\begin{abstract}
This report aims to present a clinical case of endodontic re-treatment performed on a left inferior premolar with two canals of difficult localization. The importance of anatomical knowledge and the use of an operating microscope, especially in complex reintervention are discussed. An endodontic re-treatment was performed on element 34, which had a prosthetic restoration and vestibular fistula. In clinical examination, it was observed a negative result to the sensitization test and a positive result to vertical percussion test. After all the obturating material was removed, an operating microscope was requested to assess a possible fracture or the presence of another canal. It was noticed the presence of another canal that was treated and obturated as the existing canal. After 12 months, a new radiographic exam was performed, whose result was found asymptomatic and radiographically normal. In complex peculiar anatomy cases, the operating microscope is vital for the localization of extra canal to guarantee treatment success.
\end{abstract}

Indexing terms: Endodontics. Microscopy. Premolar tooth.

\section{RESUMO}

O artigo tem como objetivo apresentar um caso clínico de retratamento endodôntico realizado em um pré-molar inferior esquerdo com dois canais de difícil localização, onde é discutida a importância dos conhecimentos anatômicos e o uso do microscópio operatório, sobretudo em reintervenções complexas. Realizou-se um retratamento endodôntico no elemento 34, possuidor de restauração protética e fístula por vestibular. No exame clínico, constatou-se resultado negativo ao teste de sensibilidade e resultado positivo ao teste de percussão vertical. Após remoção de todo o material obturador existente, o microscópio operatório foi solicitado para avaliação de uma possível fratura ou presença de outro canal. Foi constatada a presença de outro canal, o qual foi tratado e obturado como o já existente. Após 12 meses, novo exame radiográfico foi feito e constatou-se normalidade radiográfica e assintomatologia. Em casos mais complexos e com anatomia peculiar torna-se imprescindível a utilização do microscópio operatório no auxílio à localização de um canal extra para o sucesso do tratamento.

Termos de indexação: Endodontia. Microscopia. Dente pré-molar.

\section{INTRODUCTION}

A discussion topic for a number of scholars, the anatomy of root canals is one of the major challenges of endodontic treatments. The lower premolar teeth get most attention given the significant variation in the number of canals $^{1-2}$.

The endodontist must be diligent with regard to the presence of an extra canal; given that even if it is not visible in the radiograph, it doesn't mean that it doesn't exist ${ }^{3}$.

Treatment becomes more complicated when the radicular canal is infected with microorganisms ${ }^{4}$. The latter is especially observed in endodontic re-treatments in which the track of the original canal is modified during the first treatment, in addition to the presence of periradicular lesion. The degree of success of these cases, described in the literature, is lower in re-treatment with chronic apical periodontitis cases. The internal anatomy of the first inferior premolars is particularly complex due to the variation in the number of canals and their configuration ${ }^{5-6}$. Introduction of operating microscope in Endodontics redefined visualization concepts, providing image magnification ${ }^{7}$ and a higher rate of success in endodontic treatments. Variation in the number of canal treatments has changed throughout time, given that in 1955 only $8.9 \%$ of inferior premolars with more than one canal were found ${ }^{8}$. Moreover, in 1984 the authors $^{3}$ found $27.8 \%$ of two-canal teeth; and in a research ${ }^{9}$ that was carried out in 1999 with 100 in vitro diaphanous inferior premolars, they concluded that $49 \%$ of the elements bore two radicular canals.

\footnotetext{
${ }^{1}$ Faculdade Ciodonto, Departamento de Endodontia. Praça Ruy Barbosa, 185, Centro, 45653-400, Ilhéus, BA, Brasil. Correspondência para / Correspondence to: GM ALMEIDA.E-mail: <drgustavoalmeida@uol.com.br>

${ }^{2}$ Faculdade São Leopoldo Mandic, Curso de Odontologia, Programa de Pós-Graduação em Endodontia. Campinas, SP, Brasil.
} 
Castelucci ${ }^{10}$ reported the use of a microscope as one of the most important factors in the significant upturn in chances to save teeth, both surgically and non-surgically, especially in complex cases and endodontic re-interventions.

The purpose of the reported case aimed to emphasize the importance of dental anatomy knowledge and the use of an operating microscope in the identification and localization of extra canals among others. The procedure final result brings clinical success.

\section{CASE REPORT}

Patient D.R.B.O, female, 44 years old, leucoderma, came to the dentist's office with a complaint about pain in the $34^{\text {th }}$ element (1st left inferior premolar). Based on the patient's report, it was found that the tooth had been submitted twice to unsuccessful endodontic treatment. Two years after the last intervention, vestibular fistula and pain to mastication reappeared.

Anamnesis was performed and no significant alteration was observed. In clinical examination, it was observed a negative result to the sensitization test and a positive result to vertical percussion test. Clinically, the patient had a prosthetic restoration and a vestibular fistula was found in the apical palpation exam. A complementary periapical radiograph exam (Kodak Rochester, New York, USA) (Figure 1) showed a periradicular lesion with periapical bone rarefaction and a possible unobturated canal. Given the clinical-radiographic exam, endodontic re-treatment of the element was indicated, leaving periapical surgery as a last treatment option. The procedure started with the administration of anesthesia (regional block of the left inferior alveolar nerve) with articaine 4\% (DFL Indústria e Comércio S.A, Rio de Janeiro, Brazil). Surgical access was performed with the aid of ultrasound with adapted tips, TRA 24 D and TRA 15C D (Dental Trinks, São Paulo, Brazil), followed by complete isolation (rubber dam Madeitex, São José dos Campos, Brazil). Removal of gutta-percha from the canal was done with $1 \mathrm{ml}$ of eucalyptol (Fórmula \& Ação, São Paulo, Brazil) and instruments D1, D2 and D3 (ProTaper - Dentsply/Maillefer, Ballaigues, Switzerland). Instrument D1 is employed to unclog the canal cervical third; D2 is used to unclog the mid third and D3 to unclog the apical third using $2 \mathrm{ml}$ of sodium hypochlorite solution at $5.25 \%$ (Fórmula \& Ação, São Paulo, Brazil) in every file substitution. The operating microscope with a 20 times magnification (Alliance, São Paulo, Brazil) was employed to search for another possible canal, fracture or fissure, but nothing was detected. Therefore, calcium hydroxide PA (Fórmula \&
Ação, São Paulo, Brazil) associated with aqueous vehicle isotonic sodium chloride solution - (Fórmula \& Ação, São Paulo, Brazil) was applied as intracanal remedy sealed with a temporary obturator (Villevie, Joinville, Brazil). Another appointment was scheduled within 7 days.

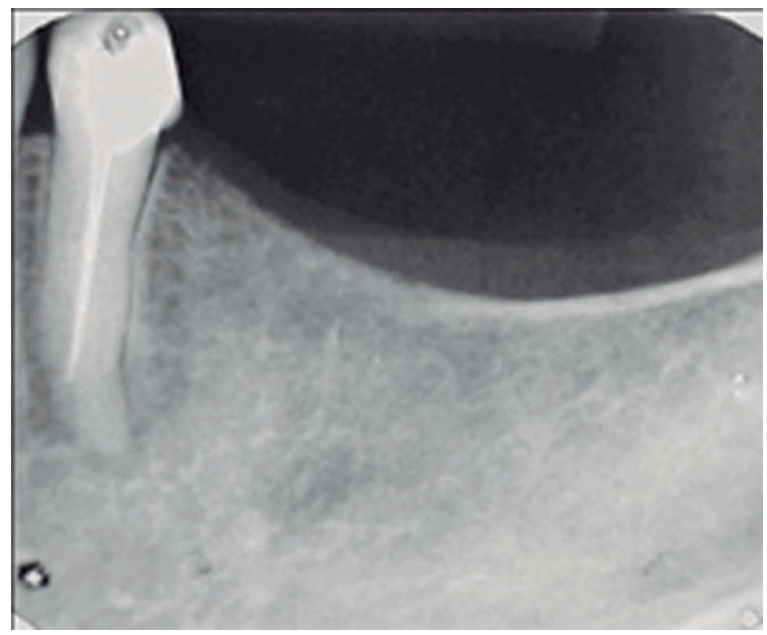

Figure 1. First X-ray.

In the second session, temporary seal was removed with total isolation, and canal was irrigated with $5.25 \%$ hypochlorite. In addition to the latter, K 10 files (Dentsply/ Maillefer, Ballaigues, Switzerland) were used to explore the canal under an operating microscope, 8X magnification (Figure 2); and posteriorly, 20X magnification at which a vestibular canal was localized. In order to confirm the exam result, a radiograph was taken with the positioned files (Figure 3) that allowed verification of the point where the canals were divided in the meso-apical direction. Dealing with this canal was difficult, given that it was obstructed with debris from previous treatments.

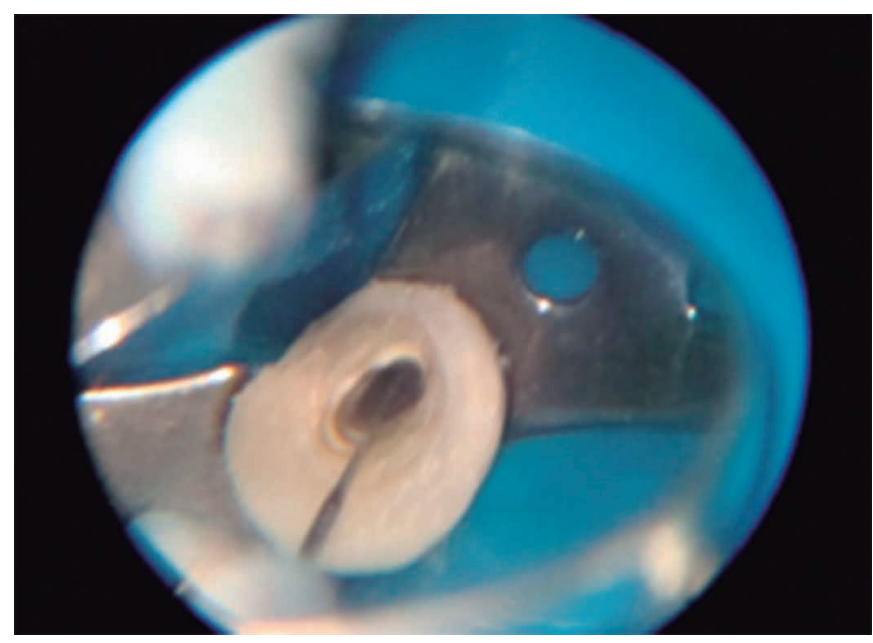

Figure 2. Operating microscope visualization (8x magnification). 


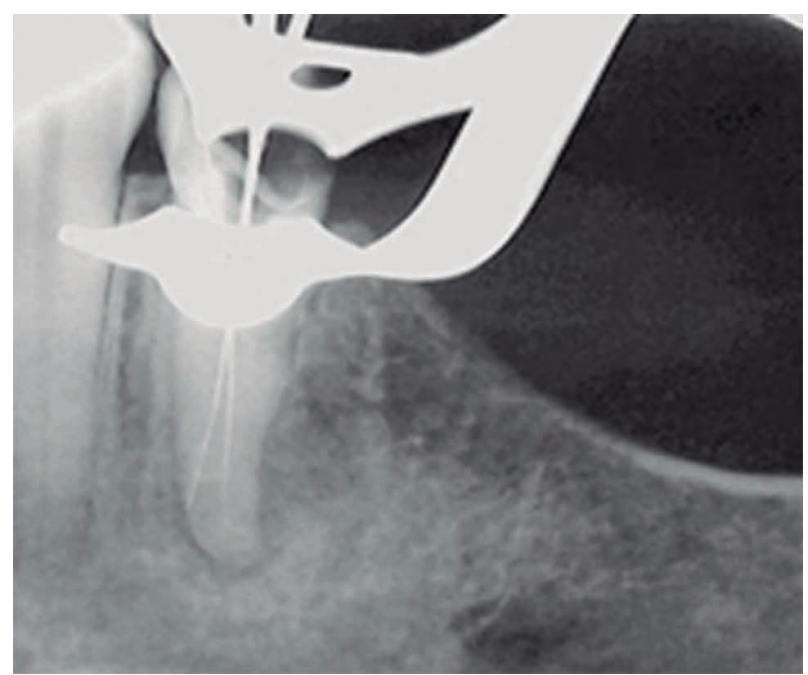

Figure 3. OM visualization.

Hence, pre-enlargement of both canals using rotary-device limes 35/10 and 20/07 ProDesign (Easy Endo, Belo Horizonte, Brazil), Gates Glidden 4, 3 and 2 (Dentsply/Maillefer, Ballaigues, Switzerland), followed by odontometry using a foraminal localizer Root ZX (J. Morita, Kyoto, Japan). After the real working extent was measured, crown-apical technique instrumentation was initiated, following the manufacturer (Easy Endo, Belo Horizonte, Brazil) recommended sequence: white file (20/03); yellow file (15/05); red file (22/04), blue file (25/04); green (20/06), and the last file, black (20/07). At each lime exchange, $2 \mathrm{ml}$ of sodium hypochlorite $5.25 \%$ was used as irrigator. After the two radicular canals were cleaned and molded, a cone test was carried out (Figure 4) using FM cones (Sparttan/ Precise-Jalisco, Mexico). It was possible to confirm by means of radiographic exam the working length measurement. Then irrigation was performed to remove the smear layer with EDTA 17\% (Formula \& Ação, São Paulo, Brazil) for 3 minutes with ultrasonic cavitations and final toilet with 5 $\mathrm{ml}$ of sodium hypochlorite at $5.25 \%$. Canals were dried with sterilized absorbent paper cones (Dentsply/Maillefer, Ballaigues, Switzerland) after the final rinsing. Subsequently, the radicular canal system was obturated with endodontic cement AHPlus (Dentsply/Maillefer, Ballaigues, Switzerland) by continuous wave of condensation technique ${ }^{11}$ (Termo Pack-Easy Endo, Belo Horizonte, Brazil). Following obturation, a provisional double cervical sealing (Villevie, Santa Catarina, Brazil) and glass ionomer Vidrion F (White, Rio de Janeiro, Brazil) were applied. Final radiography was made and directed to prosthetic restoration. Treatment was confirmed and assessed after the final radiograph was taken (Figure 5). The patient freely signed an informed consent regarding the publication and divulgence of this study case.
After 12 months, another radiographic exam was made, showing the restoration process in the periradicular region (Figure 6).

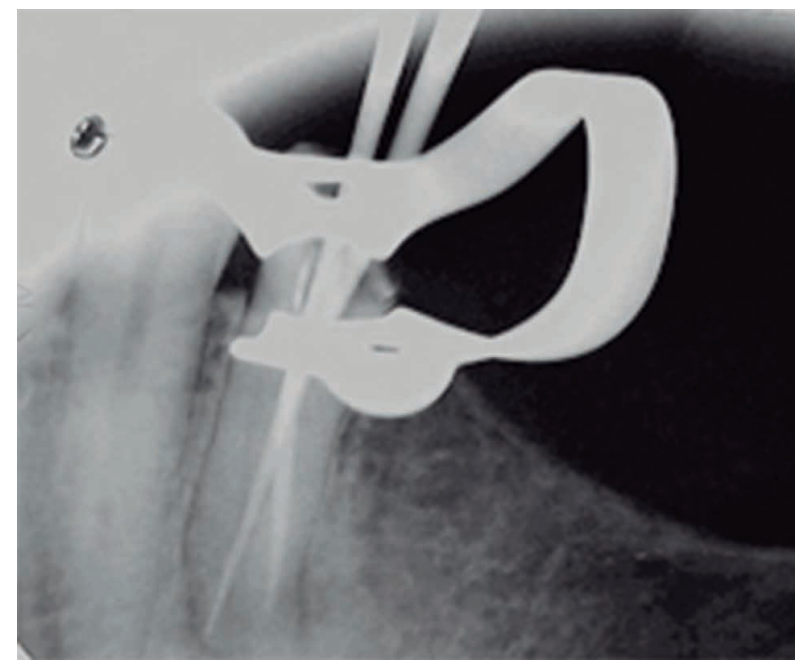

Figure 4. Cone test.

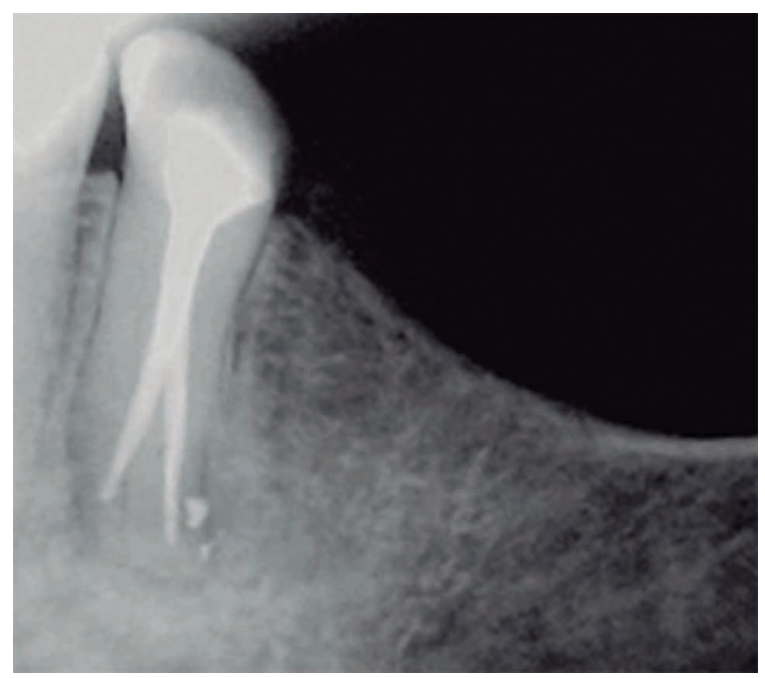

Figure 5. Last radiograph.

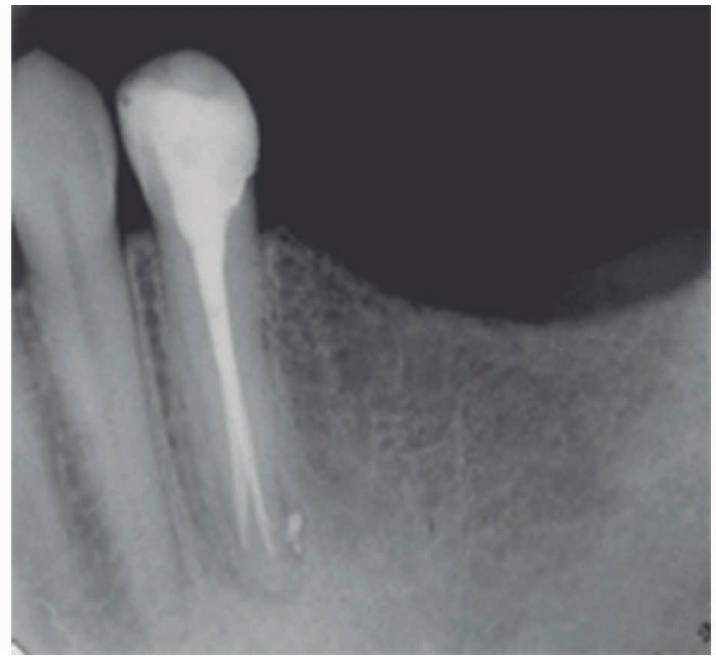

Figure 6. 12-month of follow. 


\section{DISCUSSION}

Anatomical variations in the first inferior premolar are described in the literature ${ }^{11}$. In 1973, the analysis of 1393 first inferior premolars was performed through distal and vestibular-lingual radiographic exams. The results showed the presence of one canal in $63 \%$ of the examined teeth; two canals in $22.7 \%$ of the cases, and $0.4 \%$ of the teeth presented three radicular canals ${ }^{12}$. In 1978, it was found that $74 \%$ of the 400 first inferior premolars had a sole canal, $25.5 \%$ of the samples had two canals, and only $0.5 \%$ presented three radicular canals ${ }^{13}$. These data served as basis for this report. Therefore, the presence of a second canal should be always considered, given the significant variation of internal anatomy of inferior premolars ${ }^{14}$.

Missing the presence of an extra canal may negatively affect the case outcome ${ }^{15}$. The latter was observed in this study, given that it was reported in the anamnesis that the tooth was submitted to endodontic treatment twice, with symptoms such as positive vertical percussion test, presence of vestibular fistula and periradicular lesion with periapical osseous rarefaction. This case is similar to a clinical case published in $1991^{16}$.

The existence of longitudinal fissures on the tooth root mesial face and/or vestibular face is related to radicular bifurcation ${ }^{3,9,17}$. In 1998, it was reported that the main bifurcations usually occur at the mid third or apical level ${ }^{18}$ which is in accordance with the present study. Notwithstanding, it disagrees with other authors who showed that bifurcations can occur at any root level ${ }^{19}$. Racial factor seems to exert some influence, and prevalence of two canals in the first inferior premolar is significantly greater in black people ${ }^{2,8}$.

Multiple canals can be present in a tooth whose radiographic image may be similar to a sole root; whereas multiple roots can be present and poorly defined in the radiographic exam ${ }^{20}$. However, critical radiograph analysis must be performed ${ }^{21}$ and changes to the $x$-ray beams angulations must be done in order to detect any radiographic density alterations, which suggest the presence of additional canals. In this study, it was noticed that there was no sharpness in the presence of additional canal. However, the obturated canal was medially projected

\section{REFERENCES}

1. Robinson S, Czerny C, Gahleitner A, Bernhart, Kainberger FM, Dental CT evaluation of mandibular first premolar root configurations and canal variations. Oral Surg Oral Med Oral and the other projection was distally projected, suggesting the presence of an extra canal.

In the tactile exam of the main canal walls, a previously curved small file (30 to 40 degree) must be employed with progressive stride and carefully rotated to the right and to the left with a quarter of a turn until the second canal is penetrated ${ }^{16}$. After submitting the tooth to this technique, radiograph should be made. Particular attention should be given to vestibular and lingual walls, since they cannot be viewed in the radiograph and most of the extra canals are originated on these walls with terminations at acute angles ${ }^{22-23}$. In this study, the extra canal was located distally on the lingual wall and was radiographically confirmed.

Certainly, dentistry has undergone a technological revolution in the past decades, but the real revolution is yet to come. True revolution will come when we realize that we need to keep our eyes open, given that our standard vision without the aid of magnifying glass, microscope or any other available method is unfitting to provide excellence in dentistry in every stage of clinical diagnosis up to the most complex clinical or surgical procedure ${ }^{24}$. These study findings prove, whenever it was possible to observe improvement in endodontic treatment prognosis by clinically employing an operating microscope, in agreement with other authors ${ }^{25}$ who mentioned the importance of such technology in the localization of canals that are difficult to access.

\section{CONCLUSION}

It was concluded based on the reported case and relevant literature review that inferior premolars have a wide anatomical variation, which favors the presence of extra canals. Experience and anatomy knowledge are vital prerequisites to the dental surgeon, combined with the utilization of the operating microscope that allows better lighting and visual magnification.

\section{Collaborators}

JF SANTOS, GM ALMEIDA, EF MARQUES and CES BUENO participated in all stages of this article elaboration.

Pathol Oral Radiol Endod. 2002;93(3):328-32. doi:10.1067/ moe.2002.120055

2. Trope EL, Tronstad L. Mandibular premolars with more than one root canal in different race groups. J Endod. 1986;12(8):343-5. doi:10.1016/S0099-2399(86)80035-8 
3. Leite HF, Madeira MC, Simoes S, Filho Niccoli WD, Oliveira JA, Martins AA. Estudo radiográfico da ocorrência de dois canais radiculares em primeiros pré-molares inferiores. Rev Odontol UNESP. 1984;13(1/2):113-8.

4. Kakehashi S, Stanley HR, Fitzgerald RJ. The effects of surgical exposure of dental pulps in germ-free and conventional laboratory rats. Oral Surg Oral Med Oral Pathol. 1965;20(3):3409. doi:10.1016/0030-4220(65)90171-4

5. Gorni FGM, Gagliani MM. The outcome of endodontic retreatment: a 2-yr follow - up. J Endod. 2004;30(1):1-4. doi:10.1097/00004770-200401000-00001

6. Pécora JD, Saquy PC, Neto Souza MD, Woelfel JB. Root form and canal anatomy of maxillary first premolars. Braz Dental J. 1991;2(2):87-94.

7. Carr GB. Microscopes in endodontics. J Calif Dent Assoc. 1992;20(11):55-61.

8. Amos ER. Incidence of bifurcated canals in mandibular bicuspids. J Am Dent Assoc. 1955;50(1):70-1. doi.org/10.14219/jada. archive.1955.0011

9. Silva FSP, Koga K, Silveira JCF, Nascimento CM. Variações na configuração radicular interna de pré-molares inferiores. Rev APCD, 1999;53(1):64-9.

10. Castelucci A. Magnification in endodontics: the use of operating microscope. Endoc Pract. 2003;15(5):377-84.

11. Buchanan LS. The continuous wave of condensation technique: a convergence of conceptual and procedural advances in obturation. Dent Today. 1994;13(10):80-2.

12. Zillich R, Dowson J. Root canal morphology of mandibular first and second premolars. Oral Surgery Oral Med Oral Pathol. 1973;36(5):738-44. doi:10.1016/0030-4220(73)90147-3

13. Vertucci FJ. Root canal morphology of mandibular premolars. J Am Dent Assoc. 1978;97(1):47-50. doi.org/10.14219/jada. archive.1978.0443

14. Baisden MK, Kulild JC, Weller RN. Root canal configuration of the mandibular first premolar. J Endod. 1992;18(10):505-8. doi:10.1016/S0099-2399(06)81352-X

15. Cleghorn B, Christie W, Dong C. Root and root canal morphology of the human permanent maxillary first molar: a literature review. J Endod. 2006;32(9):813-21. doi:10.1016/j. joen.2006.04.014
16. England Jr NC, Hartwell GR, Lance JR. Detection and treatment of multiple canals in mandibular premolars. J Endod. 1991;17(4):174-8. doi:10.1016/S0099-2399(06)82012-1

17. Madeira MC, Leita HF, Oliveira JA, Simões S, Niccoli Filho WD. Anatomia exterior da raiz do primeiro pré-molar inferior. Arq Cent Est Cur Odont UFMG. 1984;21(1):33-46.

18. Rios LV. Configuração interna dos pré-molares. RGO - Rev Gaúch Odontol. 1998;36(2):101-5.

19. Cohen S, Burns R. Caminhos da polpa. $6^{a}$ ed. Rio de Janeiro: Guanabara Koogan; 1997.

20. Cleghorn BM, Christie WH, Dong CC. The root and root canal morphology of the human mandibular first premolar: a literature review. J Endod. 2007;33(5):509-16. doi:10.1016/j. joen.2006.12.004

21. Pereira MGC, Baca GA, Botella LMC. Estudio de la evolución morfológica del foramen mentale y la anatomia interna de los premolares inferiores: resultados de un estúdio sobre población prehistórica, medieval y moderna. Barcelona: Editora E. T. D. S. A. Multipublicaciones; 1997

22. Yoshioka T, Villegas JC, Kobayashi C, Suda H. Radiographic evaluation of root canal multiplicity in mandibular first premolars. J Endod. 2004;30(2):73-4. doi:10.1097/00004770-200402000-00002

23. Sert S, Bayirli GS. Evaluation of the root canal configurations of the mandibular and maxillary permanent teeth by gender in the Turkish population. J Endod. 2004;30(6):391-8. doi:10.1097/00004770-200406000-00004

24. Worschech CC, Murgel CAF. Micro-odontologia: visão e precisão em tempo real. Maringá: Dental Press; 2008.

25. Alaçam T, Tinaz AC, Genç Ö, Kayaoglu G. Second mesiobuccal canal detection in maxillary first molars using microscopy and ultrasonics. Aust Endod J. 2008;34(3):106-9. doi: 10.1111/j.17474477.2007.00090.x 
